\title{
Zymogram Comparison in Three Taxa of Oncomelania, Vector Snails of Schistosomiasis
}

\author{
Masuhisa Tsukamoto', Yasuo Nakajima² and Cheng-Kuo Ghuang ${ }^{2}$ \\ 'Department of Medical Zoology, School of Medicine, University of Occupational and Environmental Health, Japan. \\ Kitakyushu 807, Japan \\ -Department of Parasitology, Yamanashi Medical College. Tamahomachi, Nakakomagun, Yamanashiken 409-38, Japan
}

\begin{abstract}
Isozyme patterns in three taxa, Oncomelania nosophora (collected from Japan), O. formosana (from Formosa), and $O$. quadrasi (from the Philippines), were compared by discontinuous electrophoresis with 5\% polyacrylamide gel. Among 16 enzymes examined, malate dehydrogenase $(\mathrm{MDH})$, esterase (Est), and glucosephosphate isomerase (GPI) showed significantly high enzyme activities, but lactate dehydrogenase (LDH), malic enzyme (ME), xanthine dehydrogenase $(\mathrm{XDH})$, hexokinase (HK), alkaline phosphatase (AIP) and aspartate aminotransferase (GOT) showed very low activities under the experimental conditions used. Band mobility was highest in leucine aminopeptidase (LAP) followed by alcohol dehydrogenase (ADH), phosphoglucomutase (PGM), acid phosphatase (AcP), isocitrate dehydrogenase (IDH), AlP, GOT, HK, glucose-6-phosphate dehydrogenase (G6PD), LDH, aldehyde oxidase (Aldox), GPI, XDH, $\mathrm{MDH}$, and ME. These enzymes demonstrated a single band (LAP, AcP, AlP, LDH, GPI, and $\mathrm{ME}$ ) or $2-3$ bands (ADH, Aldox, PGM, G6PD, MDH), but at least 10 isozyme bands were observed in Est. It is suggested that nosophora, formosana and quadrasi are closely related to each other as a species complex.
\end{abstract}

Key words: Oncomelania, snail enzymes, isozymes, electrophoresis, schistosomiasis.

(Received 15 August 1988)

\section{Introduction}

Snail species belonging to genus Oncomelania are considered to be intermediate hosts of schistosomiasis japonica. In Japan, O. nosophora was an important snail, some years ago, but the parasite Schistosoma japonicum has already been eradicated, and no new cases have occurred for many years. In Taiwan, O. formosana is not a suitable intermediate host for human schistosomiasis. In the Philippines, especially on several islands, schistosomiasis is still one of the important zoonotic diseases, and along with its vector $O$. quadrasi, should be controlled as soon as possible.

The taxonomic situation of these snails is not yet conclusive. They are considered to be either distinct species (O. hupensis, O. nosophora, O. formosana and O. quadrasi) or subspecies of Oncomelania hupensis (O. hupensis hupensis, O. hupensis nosophora, O. hupensis formosana, and $O$. hupensis quadrasi) by many investigators or in many textbooks. Therefore, basic studies on the intermediate hosts of this parasite are still important.

It has been known for some time that there were strain differences among snail species in regard to the sensitivity to S. japonicum (Hunter et al., 1952; Hsu \& Hsu, 1960). 
Information about enzyme biochemistry of these intermediate hosts are fragmental as far as we know. Chao $(1975,1978)$ examined various dehydrogenases of O. formosana in Taiwan, and found some geographic polymorphism especially in $\alpha$-hydroxybutyrate dehydrogenase isozymes. Viyanant et al. (1987) and Woodruff et al. (1988) compared isozyme banding patterns in Oncomelania hupensis from the Chinese mainland and O. h. quadrasi from the Philippines by means of isoelectric focussing and starch gel electrophoresis. They found that hupensis and quadrasi showed large differences in mobilities of several enzymes.

In the present study, detection and comparison of 16 enzymes among these taxa of snails were tried in order to discover whether or not these taxonomically distinct species of different origins demonstrate any differences in isozyme patterns by electrophoresis from the viewpoint of biochemical systematics. Although results obtained were still preliminary and the examined number of snails, populations, and enzymes were quite limited, results of the comparison of enzyme activity and electrophoretic mobility ( $R f$ value) of banding pattern are described.

\section{Materials and Methods}

Snails examined:

Oncomelania nosophora was collected from fields in Kofu and Nirasaki, Yamanashi Prefecture, Japan.

O. formosana was kindly collected by Mr. C. C. Wu of the National Yangming Medical College, Taiwan, from Chiayi, Shuili, Puyen, and Changhua, respectively, and sent to the Department of Parasitology, Yamanashi Medical College, Japan.

O. quadrasi was collected in a field on Leyte Is., the Philippines, and kept as a laboratory strain in the Hiroshima University Medical School, Japan, for several years. Due to the courtesy of Dr. H. Iwanaga, the Leyte strain was available for the present experiment.

These snails were sent to the Department of Medical Zoology, University of Occupational \& Environmental Health, Japan, then used for electrophoretic studies directly or after being kept in a deep freezer at $-70^{\circ} \mathrm{C}$ until use.

Crude enzyme preparation:

For $O$. nosophora and $O$. formosana, the shell of an individual snail was at first crushed into several pieces and the hard shell fragments were removed under a stereomicroscope. Then, a true whole body was homogenized by hand in a hole of a hard plastic dish with various volumes of $10 \mathrm{mM} 2$-mercaptoethanol solution. The smallest species, O. quadrasi, was directly homogenized without removing the shell. Amounts of the solution used were varied depending on the size of snail and/or enzyme activity to be detected: for example, in the case of quadrasi, $30 \mu \mathrm{l}$ per snail was employed, but in the largest snail, nosophora, $80 \mu \mathrm{l}$ to $100 \mu$ l of the solution per snail were used to prepare the homogenates. Individual homogenate was put into each small glass tube for microhematocrit, then centrifuged at 
$10,000 \times \mathrm{g}$ for 10 minutes at $0^{\circ} \mathrm{C}$ in a refrigerated centrifugator (TOMY MR-150). Freshly prepared supernatants were used as crude enzyme sources, but in some cases the centrifuged microtubes with the supernatant were kept at $-70^{\circ} \mathrm{C}$ in a deep freezer for a couple of days when necessary.

Electrophoresis:

Electrophoretic conditions, such as preparation of $5 \%$ polyacrylamide gel plates, $1 \mathrm{~mm}$ thickness, discontinuous buffer system, horizontal electrophoretic run, $5 \mathrm{~cm}$ migration on a cooling plate, etc. were in principle similar to those reported in a previous paper (for mosquito larvae) by Tsukamoto (1984). The following slight but important modifications were also adopted: 1) an increase of voltage of direct electric current (D.C.) from $10 \mathrm{v} / \mathrm{cm}$ to $30 \mathrm{v} / \mathrm{cm}$ to speed-up the running time without changing banding patterns, 2) brief washing of each gel with an ice-cold buffer solution after electrophoretic run, and 3) use of $0.1 \mathrm{M}$ Tris-HCl buffers of various $\mathrm{pH}$ values instead of a phosphate buffer in reaction mixtures to enhance staining intensity.

Enzymes examined:

Sixteen enzymes examined for detecting their activity as visible bands after electrophoresis are listed in Table 1. They are representatives of different groups of enzymes such as oxidoreductases, transferases, hydrolases, and isomerases.

Gel preservation:

After staining and washing, each gel was sandwiched by two cellophane sheets which were previously impregnated with $2 \%$ glycerol, then dried on a lubricated glass plate. Resultant thin films can be kept in a file for many years without the color fading.

Band mobility:

When a pH indicating dye (for example, bromophenol blue) was put on the gel at the start line, the discontinuous buffer front was easily visible as a blue line, and the electrophoretic run towards the anode was stopped when the blue line migrated at the $5 \mathrm{~cm}$ mark. After detecting enzyme activity, relative mobility of each band was calculated and expressed as Rf value:

$$
\mathrm{Rf}=\frac{\text { Migration distance of a band }}{\text { Migration distance of the buffer front }} \times 100 \text {. }
$$

\section{Results}

Detection of activity band:

Among the 16 enzymes examined, MDH, Est and GPI showed very high activity and 
Table 1. List of enzymes examined for isozyme analysis in snails

\begin{tabular}{|c|c|c|c|}
\hline Name of enzymes & Abbreviation & Code No. & Substrate \\
\hline \multicolumn{4}{|l|}{ Oxidoreductases: } \\
\hline Alcohol dehydrogenase & $\mathrm{ADH}$ & $\mathrm{EC} 1.1 .1 .1$ & n-Amyl alcohol \\
\hline Lactate dehydrogenase & $\mathrm{LDH}$ & $\mathrm{EC} 1.1 .1 .27$ & DL-lactate $\mathrm{Na}$ \\
\hline Malate dehydrogenase & $\mathrm{MIH}$ & $\mathrm{EC} 1.1 .1 .37$ & 1)I-malate $2 \mathrm{Na}$ \\
\hline Malic enzyme & $\mathrm{MF}$ & $\mathrm{EC} 1.1 .1 .40$ & 1)L-malate $2 \mathrm{Na}$ \\
\hline Isocitrate dehydrogenase & $\mathrm{IDH}$ & EG 1.1 .1 .42 & DI-isocitrate $3 \mathrm{Na}$ \\
\hline Glucose-6-phosphate dehydrogenase & G6Pl) & $\mathrm{EC} 1.1 .1 .49$ & 1.-Glucose-6-phosphate $2 \mathrm{Na}$ \\
\hline Xanthine dehydrogenase & $\mathrm{XDH}$ & $\mathrm{EC} 1.2 .1 .37$ & Xanthine $\mathrm{Na}$ \\
\hline Aldehyde oxidase & Nidox & $\mathrm{EG} 1.2 .3 .1$ & Benzaldehyde \\
\hline $\begin{array}{l}\text { Transferases: } \\
\text { Aspartate aminotransferase }\end{array}$ & GOT & EC 2.6.1.1 & $\begin{array}{l}\text { L-Aspartate } \mathrm{Na} \text { and } \\
\text { 2-Oxoglutarate } \mathrm{Na}\end{array}$ \\
\hline Hexokinase & HK & $\mathrm{EC} 2.7 .1 .1$ & D-Glucose \\
\hline Phosphoglucomutase & PGM & $\mathrm{EG} 2.7 .5 .1$ & 1)-Glucose-1-phosphate $2 \mathrm{Na}$ \\
\hline \multicolumn{4}{|l|}{ Hydrolases: } \\
\hline Non-specific esterases & Est & EC 3.1.1.- & 1-Naphthyl acetate \\
\hline Alkaline phosphatase & AlP & EC 3.1.3.1 & 1-Naphthyl phosphate $2 \mathrm{Na}$ \\
\hline Acid phosphatase & $\mathrm{AcP}$ & $\mathrm{EC} 3.1 .3 .2$ & 1-Naphthyl phosphate $\mathrm{Na}$ \\
\hline Aminopeptidase & $\mathrm{L} \Lambda \mathrm{P}$ & EC 3.4.11.1 & L-Leucyl $\beta$-naphthylamide-HCl \\
\hline $\begin{array}{l}\text { Isomerases: } \\
\quad \text { Glucosephosphate isomerase }\end{array}$ & GPI & $\mathrm{EC} 5.3 .1 .9$ & D-Fructose-6-phosphate $\mathrm{Na}$ \\
\hline
\end{tabular}

hence it was necessary to dilute the routine enzyme preparation 4 to 6 times to obtain suitable intensity of banding patterns (Fig. 1A). On the other hand, LDH, ME, XDH, HK, $\mathrm{AIP}$, and GOT showed very low or hardly detectable activity bands under the staining conditions tried (Fig. 1B). In cases of ADH, IDH, G6PD, Aldox, PGM, AcP, and LAP, enzyme activity was high enough to recognize a visible banding pattern or zymogram.

A group of enzymes, such as LDH, ME, AcP, AlP, and LAP, showed a single banding pattern, while another group of enzymes such as $\mathrm{ADH}, \mathrm{MDH}, \mathrm{IDH}$, Aldox, HK, PGM, GPI, and G6PD exhibited 2-3 bands, but Est possessed at least 10 visible bands.

Band mobility:

Band mobility of LAP was the highest followed by ADH, PGM, IDH, and AcP. Bands of AlP, GOT, G6PD-1, HK-1, Aldox-1, LDH, GPI, and HK-2, in decreasing order of $\mathrm{Rf}$ values, can be seen in the middle area of the gels. Bands of Aldox-2, XDH, G6PD3, MDH, and ME migrated slowly. Table 2 compares the relative intensity of enzyme activity and band mobility for nosophora, formosana, and quadrasi.

LAP (Fig. IC): The 3 populations of the snail formosana from Taiwan showed the highest or fastest band mobility (Rf 90) among the enzymes examined. Two populations of nosophora and one Philippine strain of quadrasi demonstrated slightly lower bands with a common $\mathrm{Rf}$ value of 87 . No individual variation of the band mobility within a population was observed.

ADH (Fig. 1D): Usually 2 bands can be observed: one major band (ADH-1) with Rf 
Table 2. Relative intensity of enzyme activity and band mobility in Oncomelania

\begin{tabular}{|c|c|c|c|c|}
\hline \multirow{2}{*}{$\begin{array}{c}\text { Isozyme } \\
\text { band }\end{array}$} & \multirow{2}{*}{$\begin{array}{l}\text { Staining } \\
\text { intensity }\end{array}$} & \multicolumn{3}{|c|}{ Band mobility (Rf) } \\
\hline & & nosophora & formosana & quadrasi \\
\hline $\mathrm{L} \Lambda \mathrm{P}$ & $H$ & 87 & 90 & 87 \\
\hline $\begin{array}{l}\text { ADH-1 } \\
\text { ADH-2 }\end{array}$ & $\begin{array}{l}H \\
+\end{array}$ & $\begin{array}{l}83 \\
77\end{array}$ & $\begin{array}{l}83 \\
77\end{array}$ & - \\
\hline $\begin{array}{l}\text { PGM-1 } \\
\text { PGM-2 }\end{array}$ & $\stackrel{+}{+}$ & $\begin{array}{l}74 \\
48\end{array}$ & $\begin{array}{c}80 \\
44,50\end{array}$ & $\begin{array}{l}80 \\
50\end{array}$ \\
\hline $\mathrm{AcP}$ & H & $73-76$ & $73-76$ & $80-82$ \\
\hline AlP & \pm & 60 & 57,60 & 63,66 \\
\hline $\begin{array}{l}\text { IDH-1 } \\
\text { IDH-2 }\end{array}$ & $\begin{array}{l} \pm-H \\
\pm-H\end{array}$ & $\begin{array}{l}72 \\
65\end{array}$ & 72 & - \\
\hline $\begin{array}{l}\text { GOT-1 } \\
\text { GOT-2 }\end{array}$ & $\begin{array}{l} \pm-+ \\
\pm-+\end{array}$ & $\begin{array}{l}60 \\
55\end{array}$ & $\begin{array}{c}60,62,64 \\
55,60\end{array}$ & - \\
\hline $\begin{array}{l}\mathrm{HK}-1 \\
\mathrm{HK}-2\end{array}$ & $\begin{array}{l} \pm \\
+\end{array}$ & $\begin{array}{l}57 \\
47\end{array}$ & $\begin{array}{c}57,64 \\
42-43\end{array}$ & - \\
\hline $\begin{array}{l}\text { G6PD-1 } \\
\text { G6PD-2 } \\
\text { G6PD-3 }\end{array}$ & $\begin{array}{l}+ \\
\pm \\
+\end{array}$ & $\begin{array}{l}54 \\
40 \\
28\end{array}$ & $\begin{array}{l}54 \\
40 \\
28\end{array}$ & - \\
\hline $\mathrm{LDH}$ & \pm & 50 & 50 & - \\
\hline $\begin{array}{l}\text { Aldox-1 } \\
\text { Aldox-1 }\end{array}$ & $\begin{array}{l}+ \\
+\end{array}$ & $\begin{array}{c}50 \\
35-37\end{array}$ & $\begin{array}{c}53 \\
35-39\end{array}$ & - \\
\hline GPI & H & 48 & 48,53 & 48 \\
\hline $\mathrm{XDH}$ & \pm & 35 & $35-39$ & - \\
\hline $\begin{array}{l}\text { MDH-1 } \\
\text { MDH-2 }\end{array}$ & 世 & $\begin{array}{l}28 \\
20\end{array}$ & $\begin{array}{l}36 \\
20\end{array}$ & - \\
\hline $\mathrm{ME}$ & \pm & 20 & 28 & - \\
\hline Est & $H$ & multiple & multiple & multiple \\
\hline
\end{tabular}

at about 83 , but the other band (ADH-2) was minor with $\mathrm{Rf}$ values of about 77 . No remarkable differences were observed between nosophora and formosana populations examined when the banding patterns were compared side by side on a single gel. Snails quadrasi have not yet been investigated.

PGM (Fig. 1E): Two banding patterns can be detected: one narrow band (PGM-1) with a higher Rf value and another broad band (PGM-2) with a lower Rf. Both quadrasi and 3 Taiwan populations of formosana possessed similar upper bands which moved slightly faster ( $R f$ 80) than those of 2 Japanese populations of nosophora ( $R f 74$ ). No remarkable individual variation in the upper band mobility within each population was noted. The broad band, however, seems to consist of 2 close bands and a slight individual variation of band mobility was observed. Snails nosophora showed a faster band, but most of the formosana strains showed a slower band.

AcP (Fig. 1F): Each snail showed a single AcP band, but some variations were observed within and among populations, i.e., Rf values were $73-76$ for nosophora and formosana, but quadrasi showed slightly faster bands (Rf $80-82$ ).

IDH: Usually a single broad band was observed, but actually the band consisted of 2 close bands. Rf values were 72 for IDH-1 and 65 for IDH-2, respectively, both in 


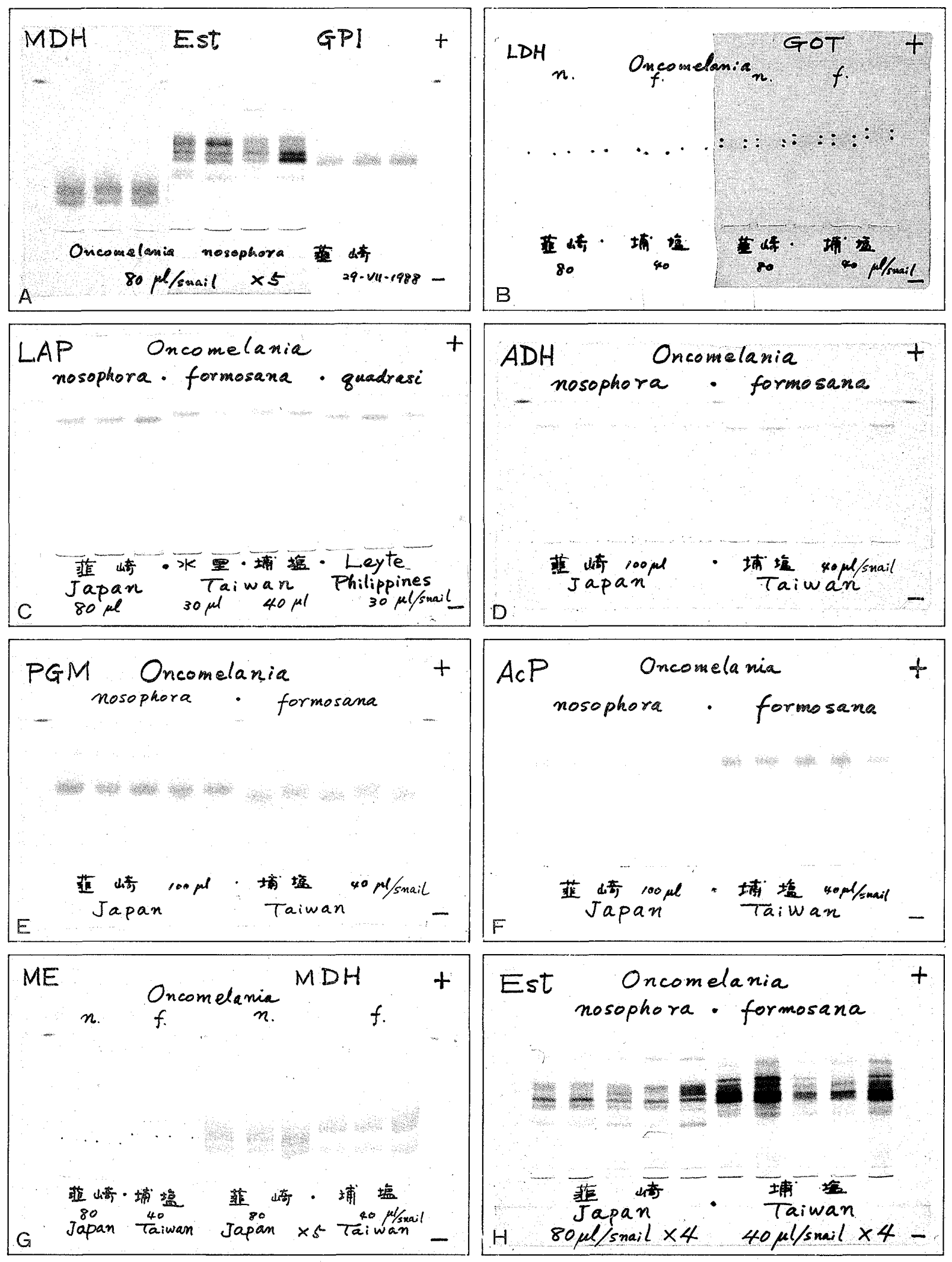


nosophora and formosana. The enzyme activity was lower in nosophora but higher in formosana.

AIP: Enzyme activity or color intensity of the band for individual snails varied extremely, probably due to physiological conditions. Sometimes no activity band is observed but some snails showed a clear band. Variations in band mobility were observed within a population: Rf values fluctuated from 57 to 66 .

GOT (Fig. 1B, right): This enzyme also exhibited a very weak and broad activity band. However, prolonged incubation of the gel in a staining mixture resulted in detecting at least 2 close bands, GOT-1 and GOT-2, of which Rf values were 60 and 55, respectively, in nosophora populations examined. In formosana, Rf values varied from 60 to 64 for GOT-1.

HK: At least two isozymes were detected, one narrow HK-1 band and another broader HK-2 band. Rf value for HK-1 was 57 in nosophora and 57 to 64 in formosana, and for HK-2 was 47 in nosophora and $42-43$ in formosana, respectively. Their staining intensity was very weak but the band position was interpretable by prolonged incubation.

G6PD: In the nosophora and formosana populations examined, usually 2 (sometimes 3) isozyme bands are observed: the 1st major band with $\mathrm{Rf} 54$, the 2nd weak band with $\mathrm{Rf}$ about 40 , and the 3 rd band with Rf at 28 in nosophora and most of the formosana population.

LDH (Fig. 1B, left): A single band can be detected at about Rf 50 position. The staining intensity of the band was sometimes extremely low but a longer incubation period (up to 2 hours) of gels resulted in detection of an interpretable band. No distinct difference in banding patterns was shown between nosophora and formosana whereas a slight variation of mobility was observed in a formosana population.

Aldox: This enzyme showed 2 isozyme bands, an upper and sharp minor band (Aldox-1) and a lower major one (Aldox-2). The latter seems to consist of a further one or two close bands. The Rf value for Aldox-1 band was about 50 in nosophora, and mostly 53 in formosana, respectively. The Rf values for Aldox-2 band were 35 to 37 in nosophora and 35 to 39 in formosana, respectively.

GPI (Fig. 1A, right): Enzyme activity was very strong in routine enzyme preparations and hence one can demonstrate visible bands after dilution to 5 times with the 2mercaptoethanol solution. One major band was detected. The $\mathrm{Rf}$ value was 48 in nosophora and quadrasi, but some populations of formosana showed polymorphism, suggesting a

Fig. 1. Electrophoretic banding patterns of various enzymes in Oncomelania snails. Each lane represents a banding pattern of individual snails.

A: Malate dehydrogenase, non-specific esterases and glucosephosphate isomerase (left to right, respectively) in $O$. nosophora. Enzyme activities are high enough to observe visible bands even after $5 \times$ dilution of the routine enzyme preparation. B: Lactate dehydrogenase (left) and aspartate transaminase (right) in nosophora (n.) and formosana (f.). Enzyme activities are extremely weak in some enzymes, and hence a prolonged incubation period is necessary to detect visible bands. $C$ : Leucine aminopeptidase. D: Alcohol dehydrogenase. E: Phosphoglucomutase. F: Acid phospohatase. G: Malic enzyme and malate dehydrogenase. H: Non-specific esterases. 
mixture of a faster band ( $\operatorname{Rf} 53)$ and the slower band ( $\mathrm{Rf} 48$ ).

XDH: Enzyme activity detected was very weak but interpretable as a single band by a prolonged incubation. Its $\mathrm{R} f$ value was 35 in nosophora and 35 to 39 in both formosana and quadrasi, respectively.

MDH (Figs. 1A, left; $1 G$, right): As enzyme activity was very strong in snails examined, in order to demonstrate a clear banding pattern, it was necessary that the routine concentration of enzyme extracts be diluted $4-6$ times. Two major bands, MDH-1 and MDH-2, were observed in each population. Band mobility of MDH-1 of formosana (Puyen population) was always higher ( Rf 36) than that of nosophora ( $\mathrm{Rf} 28)$ but the MDH-2 band was common between nosophora and formosana (Rf 20).

ME (Fig. 1G, left): This enzyme also showed extremely low activity bands with Rf values of 20 for nosophora and 28 for formosana (Puyen population), respectively.

Est (Figs. 1A, middle; 1H): So-called non-specific esterases were examined by using 1naphthyl acetate as a substrate of the enzyme. Enzyme activity was exceedingly high enough to detect as bands even after 5 times dilution of the usual enzyme extract. Each snail possessed more than 10 sharply separated isozymes spreading over widely towards the anodal buffer front. Enzyme polymorphism was observed in several bands both within and between populations in all 3 taxa of snails.

\section{Discussion}

Taxonomic recognition of snail species was mostly based on morphological characters. Present results of the zymograph comparison indicated that there are no discriminating biochemical gaps to reflect their taxonomic classification among the Oncomelania species complex from Japan, Taiwan, and the Philippines. Namely, some enzyme banding patterns (expressed as $\mathrm{Rf}$ values) are common in a combination of at least two taxa of snails, for example:

$$
\begin{aligned}
& \text { nosophora }=\text { formosana }<\text { quadrasi in AcP, } \\
& \text { nosophora }<\text { formosana }=\text { quadrasi in PGM-1, } \\
& \text { nosophora }=\text { quadrasi }<\text { formosana in LAP, and } \\
& \text { nosophora }=\text { formosana }=\text { quadrasi in GPI. }
\end{aligned}
$$

When isozyme polymorphism within a population or a taxon is distinct (like Est), differences among populations or taxa might be easily overlooked. This suggests that they are not separable from each other from a viewpoint of comparative biochemistry.

In addition, morphology of the shell surface is also distinctly different. O. hupensis has remarkable longitudinal ridges, whereas 3 sibling species or subspecies from Japan, Formosa and the Philippines have a smooth surface. According to electrophoretic studies by Viyanant et al. (1987) and Woodruff et al. (1988), it was also suggested that O. hupensis of 
the Chinese mainland seems to be a distinct species from O. quadrasi of the Philippines.

Therefore, from such an overall consideration of morphological and biochemical characteristics, we can assume that nosophora, formosana, and quadrasi may belong to a species complex or closely related sibling species but may not be subspecies belonging to Oncomelania hupensis. In order to obtain more conclusive results, it will be necessary to compare zymograms of these snails and $O$. hupensis of the Chinese mainland.

\section{Acknowledgment}

We are deeply thankful to Professor P. C. Fan and Mr. C. C. Wu of the National Yangming Medical College, Taipei, for their kind collaboration by collecting and sending snails of field populations of O. formosana; to Professor M. Tsuji and Dr. Y. Iwanaga of the Hiroshima University Medical School, Hiroshima, for their useful advice and kind permission to use the Leyte strain of $O$. quadrasi. Sincere appreciation is due to Miss H. Tobata for laboratory assistance. We also wish to express our special thanks to Professor D. Chao of the National Sun Yat-Sen University, Taiwan, for Chinese references, and to Professor D. S. Woodruff of the University of California, San Diego, for a copy of page proofs of their prepublication.

(A part of this work is presented at the 5th Sino-Japanese Symposium on Parasitic Zoonoses held at Taipei, China, on August 20-21, 1988)

\section{References}

Chao, D. (1975): Proteins and dehydrogenase isozymes of recombinants of Oncomelania hupensis formosana from different localities in Taiwan. Dissertation, M.Ph., Natl. Taiwan Univ. 61 pp. (in Chinese)

Chao, D. (1978): Study on $\alpha$-hydroxybutyrate dehydrogenase isozyme of Oncomelania hupensis formosana from different localities in Taiwan. Bull. Malacol., 5: 69-76. (in Chinese with English summary)

Hsu, S. Y. \& Hsu, H. F. (1960): Infectivity of the Philippine strain of Schistosoma japonicum in Oncomelania hupensis, O. formosana and O. nosophora. J. Parasitol., 46: 793-796.

Hunter, G. W., Ritchie, L. S. \& Otori, Y. (1952): A comparison of the infectivity of Schistosoma japonicum occurring in Japan for Oncomelania nosophora and Oncomelania formosana. J. Parasitol., 38: 492.

Tsukamoto, M. (1984): Technical notes on acrylamide gel electrophoresis used for comparing isozymes of mosquito larvae. J. UOEH, 6: 193-204.

Viyanant, V. \& Upatham, E. S. (1988): Schistosomiasis japonica: Epidemiology and genetic aspects. Southeast Asian J. Trop. Med. Pub. Hlth., 19: 139-150.

Viyanant, V., Upatham, E. S., Blass, B. L. et al. (1987): Analysis of allozymes by electrofocussing in schistosome snail hosts (Oncomelania hupensis) from China and the Philippines. Malacol. Rev., 20: 91- (cited from Viyanant \& Upatham, 1988).

Woodruff, D. S., Staub, K., Upatham, E. S. et al. (1988): Schistosome transmitting snails (Oncomelania hupensis complex) from China and the Philippines are different species. Malacologia, 29: 347-361. 
住血吸虫症媒介貝の酵素泳動像比較

塚本 増久 ${ }^{1} \cdot$ 中島 康雄 ${ }^{2} \cdot$ 荘 和憲 ${ }^{2}$

1産業医科大学医動物学教室 '山梨医科大学寄生虫学教室

要旨：人畜の日本住血吸虫症を媒介するミヤイリガイ Oncomelania nosophora（日本），抒よびその 近縁種 O. formosana (台湾)，O. quadrasi（フィリピン）の分類については，互に独立種ま たは O. hupensis (中国大陸) の亜種とみなされている.しかしこれらの3 種類は形態的に も O. hupensis とはかなり異なっているので，16 種類の酵素について電気泳動像を比較し た.そのうち，エステラーゼ（Est），リンゴ酸脱水素酵素 $(\mathrm{MDH})$ ，グルコース燐酸イソ メラーゼ（GPI）は極めて高い酵素活性を示した。一方，乳酸脱水素酵素（LDH），リン

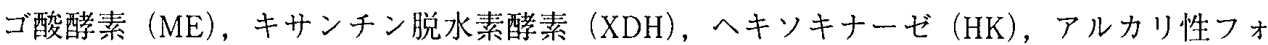
スファターゼ (AlP)，アスパラギン酸アミノ転移酵素（GOT）などの活性は極めて低く， 長時間インキュベートしなければ発色バンドとして検出することは困難であった。また， バンドの泳動速度はロイシンアミノペプチダーゼ（LAP）が最も速く，アルコール脱水素

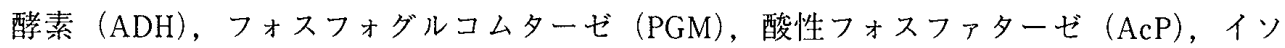
クエン酸脱水素酵素 (IDH)，GOT, HK，グルコース 6 燐酸脱水素酵素 (G6PD)，LDH，ア ルデヒド酸化酵素 (Aldox)，GPI, XDH, MDH, MEの順に遅く泳動された。なお, LDH, ME, AcP, AlP, LAP, GPI などは 1 本のバンドを示したが, ADH, MDH, IDH, Aldox, HK, PGM, G6PD などでは $2 \cdot 3$ 本のバンドが, Est では 10 本以上のバンドが検出された。こ れらのバンドの泳動像は酵素と貝の種類によってゃや異なるものもあったが，全体として は極めてよく似ており，生化学的にも互に類縁関係が密接であることをうかがわせた.

J. UOEH（産業医大誌)，10 ( 4): 381-390 (1988) 